\title{
Nutritional and sensory characteristics of Minas fresh cheese made with goat milk, cow milk, or a mixture of both
}

\author{
A. M. S. Sant'Ana, ${ }^{*}$ F. F. Bezerril, ${ }^{*}$ M. S. Madruga, $\dagger$ A. S. M. Batista, ${ }^{*} M$. Magnani, $\dagger$ E. L. Souza, $\ddagger$ \\ and R. C. R. E. Queiroga*1 \\ *Laboratory of Food Science, Department of Nutrition, \\ †Laboratory of Analysis and Food Quality Control, Department of Food Engineering, and \\ łLaboratory of Microbiology, Department of Nutrition, Federal University of Paraíba, João Pessoa-PB 58051-900, Brazil
}

\section{ABSTRACT}

This study aimed to assess and compare the nutritional, technological, and sensory characteristics of Minas fresh cheese made with goat milk, cow milk, or a mixture of the two stored in cold conditions for 21 d. The yield and centesimal composition of the cheeses were not affected by the type of milk used in their preparation. Reductions were observed in the moisture content, $\mathrm{pH}$, proteolysis index, and instrumental hardness; moreover, increases were observed in the syneresis, acidity index, and depth of proteolysis index in all cheeses. The percentages of caprylic, capric, oleic, and linoleic fatty acids were higher in goat milk cheese and cheese made with a mixture of goat and cow milk compared with cow milk cheese, and a sensory evaluation revealed differences in color, flavor, and aroma between the cheeses. The preparation of Minas fresh cheese with a mixture of goat and cow milk can be a viable alternative for dairy products in the market that can be characterized as high-quality products that meet consumer demands.

Key words: goat raising, dairy product, quality, cheese

\section{INTRODUCTION}

Minas fresh cheese is one of the most traditional dairy products produced in Brazil, which outstandingly accepts it in the domestic market (Souza and Saad, 2009). The ubiquity of this cheese is defined by its high yield, simple manufacturing process, low cost, and acceptance by most consumers, all of which garner the interest of the cheese industry. Minas fresh cheese that is produced from the enzymatic coagulation of milk with rennet, with or without starter cultures, exhibits a soft texture, a slightly acidic flavor, and a high moisture content and should be consumed shortly after

Received April 10, 2013.

Accepted September 5, 2013.

${ }^{1}$ Corresponding author: rcqueiroga@uol.com.br production (within 20 d; Andreatta et al., 2009; Souza and Saad, 2009).

Cheeses made with goat milk are consumed worldwide and have been associated in recent years with increased goat milk production and demand in numerous countries (dos Santos et al., 2012; Queiroga et al., 2013). However, a lack of technology and research characterizing dairy products made with goat milk limit its expansion in the market. In addition, the sensory aspects of goat products, such as a more intense flavor and aroma, also contribute to the low acceptance of these products by some consumers (Dubeuf, 2005).

In this context, partial substitution of goat milk for cow milk in dairy products, such as cheeses, offers an alternative for consumers who wish to consume more goat dairy products (Sheehan et al., 2009). This partial substitution of goat milk with cow milk may represent an opportunity to diversify the dairy market because it may add value and unique characteristics in comparison to products made only with cow milk (Vargas et al., 2008). These features are largely related to the chemical composition of goat milk, which consists of proteins with high biological value and a lower allergenic potential. These characteristics are related to the quantity and structural differences of whey proteins $(\alpha-\mathrm{LA}$ and $\beta-\mathrm{LG})$ and to small-diameter fat globules, which allow for higher digestibility compared with cow milk. In addition, goat milk harbors a higher mineral content (calcium, iron, zinc, and magnesium), a higher vitamin content (A and B complexes) and has less atherogenic FA, which characterize it as a highly nutritious food for consumers (Haenlein, 2004; Park et al., 2007; Slačanac et al., 2010).

Considering these aspects, studies that evaluate the characteristics of cheeses made with goat milk and that discuss innovative technologies for developing these products are vital for disseminating the technological and nutritional advantages of goat milk, with the goal of enhancing goat milk production. We aimed to develop and assess some of the nutritional, technological, and sensory parameters of Minas fresh cheese produced 
with a mixture of goat and cow milk, which were compared with the characteristics observed for Minas fresh cheese made with goat or cow milk alone.

\section{MATERIALS AND METHODS}

\section{Experimental Design and Raw Materials}

Three different cheese types were made in triplicate at 3 different times, from the same milk batch. The following 3 treatments were adopted, using a randomized experimental design: cheese made with cow milk (CCM; 100\%); cheese made with goat milk (CGM; $100 \%$ ); and cheese (CCGM) made with a mixture of cow milk (50\%) and goat milk (50\%). Cow (Girolando breed) and goat milk (Alpine breed) samples were obtained from the Department of Production, Federal University of Paraíba (Bananeiras, Paraíba, Brazil). The average physicochemical values for $100 \mathrm{~g}$ of goat milk (in g; means $\pm \mathrm{SD}$ ) were protein, 3.75 $( \pm 0.32)$; fat, $3.35( \pm 0.13)$; ash, $0.73( \pm 0.09)$; lactose, $4.31( \pm 0.01)$; and TS, $11.40( \pm 0.26)$, with a $\mathrm{pH}$ of 6.48 $( \pm 0.03)$, whereas the values for $100 \mathrm{~g}$ of cow milk were (in g) protein, $4.33( \pm 0.39)$; fat, $3.23( \pm 0.21)$; ash, 0.70 $( \pm 0.07)$; lactose, $5.79( \pm 0.02)$; and TS, $12.60( \pm 0.56)$, with a $\mathrm{pH}$ of $6.87( \pm 0.01)$.

\section{Manufacture of Minas Fresh Cheese}

The cheeses were manufactured following the procedure described by Buriti et al. (2005). Goat and cow milk were heat treated $\left(65^{\circ} \mathrm{C} / 30 \mathrm{~min}\right)$, cooled to $37^{\circ} \mathrm{C}$, and $0.01 \mathrm{~g} / \mathrm{L}$ of lyophilized mesophilic starter culture DVS (R-704 Lactococcus lactis ssp. lactis and Lactococcus lactis ssp. cremoris; Chr. Hansen Indústria e Comércio Ltda, Valinhos, Brazil) was added by direct inoculation. Fifty percent calcium chloride $(0.5 \mathrm{~mL} / \mathrm{L})$ and $0.8 \mathrm{~mL} / \mathrm{L}$ of commercial rennet (Ha-La; Chr. Hansen Indústria e Comércio Ltda) were added. The cultures remained at rest $\left(37^{\circ} \mathrm{C}\right)$ until a firm curd was observed (approximately $40 \mathrm{~min}$ ), which was smoothly cut into cubes, slowly stirred for $20 \mathrm{~min}$, and salted in brine $(15 \mathrm{~g}$ of $\mathrm{NaCl} / \mathrm{kg})$ while the cheese whey was partially removed. The curd was placed in a perforated circular container (10-cm diameter) and stored at $4^{\circ} \mathrm{C}$ for $24 \mathrm{~h}$. The cheese obtained after storage at $4^{\circ} \mathrm{C}$ for $24 \mathrm{~h}$ was regarded as the final product. The cheeses were vacuum packaged in sterile polyethylene bags and stored for $21 \mathrm{~d}$ at $4^{\circ} \mathrm{C}$.

\section{Analyses}

The final product (stored at $4^{\circ} \mathrm{C}$ for $24 \mathrm{~h}$ ) and cheeses stored for 7,14 , and $21 \mathrm{~d}\left(\right.$ at $4^{\circ} \mathrm{C}$ ) were submitted to physical, chemical, proteolytic, and instrumental texture analyses after 25 -g portions were aseptically collected. The FA profile determinations and sensory analyses were conducted after 7 and 14 d of storage.

\section{Yield and Syneresis}

The yield of each formulation was expressed as the ratio between the mass of fresh cheese produced and the milk volume used ( $\mathrm{kg}$ of cheese/L of milk; FritzenFreire et al., 2010). Syneresis was calculated as the whey mass (in grams) released from each cheese sample in its own package after different storage periods divided by the cheese mass (in grams) in the same packaging multiplied by 100 (Souza and Saad, 2009).

\section{Microbiological Analyses}

To evaluate the microbiological quality of the raw materials and cheeses, we quantified the total and thermotolerant coliforms (most probable number/g), the coagulase-positive staphylococci (cfu/g) and verified the presence of Salmonella spp. and Listeria monocytogenes, according to the methodology recommended by the American Public Health Association (APHA, 2001).

\section{Physicochemical Analyses}

The moisture (method 925.09), fat (method 2000.18), lactose (method 923.09), ash (method 930.30), and acidity (g/100 g of lactic acid; method 920.124) were analyzed according to the AOAC International (2005) guidelines. The total protein was estimated by the Kjeldahl method (method 939.02) using a conversion factor of 6.38 . The cheese $\mathrm{pH}$ was determined using a digital pH meter (model Q400AS; Quimis, Diadema, São Paulo, Brazil).

\section{Instrumental Color Analysis}

The CR-300 colorimeter (Minolta Co., Osaka, Japan) was used for instrumental color evaluation. The CIE Lab color scale (where $\mathbf{L}^{*}$ represents the lightness of the color, $\mathbf{a}^{*}$ represents its position between red/magenta and green, and $\mathbf{b}^{*}$ represents its position between yellow and blue) was used with a D65 illuminate (standard daylight) at a $10^{\circ}$ angle. The $\mathrm{L}^{*}, \mathrm{a}^{*}$, and $\mathrm{b}^{*}$ parameters were determined according to the International Commission on Illumination (CIE, 1996). Using reference plates, the apparatus was calibrated in the reflectance mode, and the specular reflection was excluded. A 10-mm quartz cuvette was used for analyz- 
ing the inner section of the cheeses immediately after unpacking (Queiroga et al., 2013).

\section{Proteolysis Analysis}

Cheese proteolysis was assessed by analyzing the extent of the proteolysis index (EPI) and the depth of the proteolysis index (DPI), calculated with the following equations:

$$
\begin{gathered}
\mathrm{EPI}=\mathrm{SN} \text { at } \mathrm{pH} 4.6 / \mathrm{TN} \times 100 ; \\
\mathrm{DPI}=\mathrm{SN} \text { in } \mathrm{TCA} / \mathrm{TN} \times 100,
\end{gathered}
$$

where $\mathrm{SN}=$ soluble $\mathrm{N}$ and $\mathrm{TN}=$ total $\mathrm{N}$.

Total nitrogen was determined by the Kjeldahl method (AOAC International, 2005). Trichloroacetic acid-soluble $\mathrm{N}$ was obtained by protein precipitation in TCA at $1.2 \mathrm{~g} / \mathrm{L}$. Soluble $\mathrm{N}$ at a $\mathrm{pH}$ of 4.6 was obtained by casein precipitation with acetic acid and sodium acetate solutions ( $\mathrm{pH}=4.6$; Andreatta et al., 2007).

\section{Texture Profile Analysis}

The texture profile analyses were performed using the texture analyzer TA-XT2 (Stable Micro Systems Ltd., Godalming, UK). A 2-bite compression test was applied to the cheese samples $(5.0 \mathrm{~cm}$ in diameter and $2.0 \mathrm{~cm}$ in height) by a cylindrical acrylic probe with a $25-\mathrm{mm}$ diameter. The compression ratio was set to $2 \mathrm{~mm} / \mathrm{s}$ and the maximum penetration was set to 10 $\mathrm{mm}$. All the determinations were repeated 6 times for each cheese.

\section{FA Profile}

After total lipid extraction performed according to Folch et al. (1957), which was followed by saponification and esterification, performed according to Hartman and Lago (1973), the FA profiles of the cheese samples were determined by a Varian 430-GC gas chromatograph (Varian Inc., Palo Alto, CA), with a flame ionization detector, a fused-silica capillary column (Varian CP WAX 52 CB; Varian Inc.), and a harboring film with dimensions of $60 \mathrm{~m} \times 0.25 \mathrm{~mm} \times 0.25 \mathrm{~mm}$. Helium was used as the carrier gas at a flow rate of $1 \mathrm{~mL} / \mathrm{min}$. The initial oven temperature of $100^{\circ} \mathrm{C}$ was increased $2.5^{\circ} \mathrm{C} / \mathrm{min}$ to a final temperature of $240^{\circ} \mathrm{C}$ for $20 \mathrm{~min}$, totaling $76 \mathrm{~min}$. The injector and detector temperatures were maintained at 250 and $260^{\circ} \mathrm{C}$, respectively. Aliquots of esterified extracts $(1.0 \mu \mathrm{L})$ were injected into a split/splitless-type injector at $250^{\circ} \mathrm{C}$, and the chromatograms were recorded using Galaxie Chromatography Data System software (Agilent Technologies
Inc., Santa Clara, CA). Fatty acids were identified by comparing the methyl ester retention times with standards from the Supelco ME19-Kit (FA methyl esters C6-C24; Supelco Inc., Bellefonte, PA). The FA results were expressed as percent area after normalizing to the methyl ester area.

\section{Sensory Analysis}

Sensory evaluation of Minas fresh cheeses was performed by the quantitative descriptive analysis technique (Stone and Sidel, 1993) and the purchase intent. For the quantitative descriptive analysis test, 10 trained panelists (aged 20-30 yr), recruited and preselected based on their discriminate sensory capacity, described the cheese sensory characteristics. The panelists participated in 11 training sessions ( $1 \mathrm{~h}$ for each session) to develop their descriptive terminology and to familiarize themselves with the reference materials (Table 1 ). The samples were characterized based on appearance (smooth, whitish, creamy color, and wetness), aroma (goat milk and butter), flavor (goat milk, butter, acidity, and salty), and texture (softness and homogeneity). An unstructured scale from 0 (poor) to 9 (strong) was used to assess the intensity of the attributes described.

The purchase intent test was assessed with 100 untrained evaluators, using a 5 -point structured scale that ranged from 1 (definitely would not buy) to 5 (certainly would buy). These evaluators were recruited from students, employees, and professors of the Federal University of Paraíba (João Pessoa, Brazil) and selected according to interest and Minas fresh cheese habit of consumption.

The analyses were performed in individual booths with white illumination. Each assessor was served of $20 \mathrm{~g}$ of each cheese sample placed on small white plates coded with 3-digit random numbers served immediately after being taken out of refrigerated storage. Assessors were asked to use low-salt crackers and water to clean their palates between the assessed samples.

\section{Statistical Analysis}

The 3 replicates were analyzed in triplicate. The data were submitted to an ANOVA, and the treatment means were compared using the Tukey test, where $P$ $<0.05$. For sensory analysis, a principal components analysis was also performed, and SAS software (version 9.1; SAS Institute, 2002) was used for statistical analysis.

\section{RESULTS AND DISCUSSION}

During the evaluated storage time interval, the total and thermotolerant coliform counts for CCM, CCGM, 
Table 1. Sensory attributes determined by the panel of evaluators, their definitions, and references that define the extremes of the unstructured scale

\begin{tabular}{|c|c|c|}
\hline Descriptor term & Definition & Reference \\
\hline \multicolumn{3}{|l|}{ Appearance } \\
\hline Smooth appearance & Product smooth, continuous without granules or holes ("eyes") & $\begin{array}{l}\text { Weak: a piece of Ricotta cheese }(8 \times 6 \mathrm{~cm}) \text { under the brand name of Bom } \\
\text { Leite; strong: a piece of UF Minas fresh cheese }(8 \times 6 \mathrm{~cm}) \text { under the brand } \\
\text { name of Danubio }\end{array}$ \\
\hline Whitish color & Characteristic color of goat cheese, tending to white & $\begin{array}{l}\text { Weak: a piece of goat Coalho cheese }(8 \times 6 \mathrm{~cm}) \text { under the brand name of } \\
\text { Semear; strong: a piece of artisan goat Minas fresh cheese }(8 \times 6 \mathrm{~cm})\end{array}$ \\
\hline Creamy color & Yellowish-white color, similar to the color of the butterfat & $\begin{array}{l}\text { Weak: a piece of goat Coalho cheese }(8 \times 6 \mathrm{~cm}) \text { under the brand name of } \\
\text { Semear; strong: a piece of Parmesan cheese }(8 \times 6 \mathrm{~cm}) \text { under the brand name } \\
\text { of Ipanema }\end{array}$ \\
\hline Wet appearance & The amount of liquid released, present on the surface of the cheese & $\begin{array}{l}\text { Weak: a piece of Ricotta cheese }(8 \times 6 \mathrm{~cm}) \text { under the brand name of Bom } \\
\text { Leite; strong: a piece of UF Minas fresh cheese }(8 \times 6 \mathrm{~cm}) \text { under the brand } \\
\text { name of Danubio }\end{array}$ \\
\hline
\end{tabular}

Aroma

Goat milk aroma Characteristic aroma of cheese from goat milk

Butter aroma Characteristic aroma of butter

Flavor
Goat milk flavor $\quad$ Intensity of the goat flavor

Butter flavor Intensity of cow milk fat taste

Acidity flavor Taste on the tongue stimulated by acids such as lactic acid

Salty flavor Taste on the tongue stimulated by salts such as sodium chloride name of Danubio

Weak: a piece of goat Coalho cheese $(8 \times 6 \mathrm{~cm})$ under the brand name of Semear; strong: a piece of artisan goat Minas fresh cheese $(8 \times 6 \mathrm{~cm})$

Weak: a piece of UF Minas fresh cheese $(8 \times 6 \mathrm{~cm})$ under the brand name of

Danubio; strong: a piece of Parmesan cheese $(8 \times 6 \mathrm{~cm})$ under the brand name of Ipanema

Weak: a piece of goat Coalho cheese $(8 \times 6 \mathrm{~cm})$ under the brand name of Semear; strong: a piece of artisan goat Minas fresh cheese $(8 \times 6 \mathrm{~cm})$

Weak: a piece of Ricotta cheese $(8 \times 6 \mathrm{~cm})$ under the brand name of Bom Leite; strong: a piece of UF Minas fresh cheese $(8 \times 6 \mathrm{~cm})$ under the brand name of Danubio

Weak: a piece of UF Minas fresh cheese $(8 \times 6 \mathrm{~cm})$ under the brand name of Danubio; strong: a piece of artisan goat Minas fresh cheese $(8 \times 6 \mathrm{~cm})$

Weak: a piece of Ricotta cheese $(8 \times 6 \mathrm{~cm})$ under the brand name of Bom

Leite; strong: a piece of Parmesan cheese $(8 \times 6 \mathrm{~cm})$ under the brand name of Ipanema

Weak: a piece of Parmesan cheese $(8 \times 6 \mathrm{~cm})$ under the brand name of Ipanema; strong: a piece of UF Minas fresh cheese $(8 \times 6 \mathrm{~cm})$ under the brand name of Danubio

Soft texture Texture property related to a low resistance to chew

Homogeneous texture Texture property related to the no-lumps perception during chewing

Weak: a piece of Ricotta cheese $(8 \times 6 \mathrm{~cm})$ under the brand name of Bom

Leite; strong: a piece of UF Minas fresh cheese $(8 \times 6 \mathrm{~cm})$ under the brand name of Danubio

of Danubio


and CGM were less than 3 most probable number/g, and the presence of coagulase-positive staphylococci, Salmonella spp., and L. monocytogenes was not detected, demonstrating a satisfactory microbiological quality for the analyzed cheeses according to the microbiological criteria established by the Brazilian legislation (Agência Nacional de Vigilância Sanitária, 2001).

\section{Yield and Proximate Composition}

Minas fresh cheese production yielded a range of 17.61 to $19.40 \mathrm{~kg} / \mathrm{L}$ and was not affected $(P>0.05)$ by the type of milk used (Table 2). The cheese yield largely depended on the milk composition, particularly the fat and protein content (Guo et al., 2004). Goat milk exhibits higher NPN levels and lower casein nitrogen levels than cow milk (Park et al., 2007), which may result in lower yields when manufacturing cheese made with goat milk (Guo, 2003) compared with cow milk. However, we did not observe such results in this study. The similarity in the cheese yields, regardless of the milk type used in their production, may be related to the goat breed from which milk was obtained. Milk from Alpine goats has been shown to exhibit a high percentage of $\alpha_{\mathrm{s} 1}-\mathrm{CN}$, which has been associated with higher cheese yields and firmer curds compared with milk from animals with lower $\alpha_{\mathrm{s} 1}$-CN percentages (Tziboula-Clarke, 2003; Moatsou et al., 2004).

The CCM, CCGM, and CGM did not differ $(P>$ $0.05)$ with regard to their centesimal composition, except for the lactose content $(P<0.05)$, which was lower in CGM than in CCM. This finding may be related to the lactose content of the goat milk used to prepare CGM, which was lower than the lactose in cow milk. Queiroga et al. (2013) previously observed that fresh cheese made with cow milk displayed a higher moisture content and a lower fat content compared with cheese made with goat milk or a mixture of both, suggesting that manufacturing differences can influence the final cheese composition, independent of the milk source.

\section{Titratable Acidity, pH, Syneresis, and Moisture Content During Refrigerated Storage}

Titratable acidity increased $(P<0.05)$ throughout the storage period assessed, accompanied by a $\mathrm{pH}$ reduction in all the cheese samples (Figures $1 \mathrm{a}$ and $1 \mathrm{~b}$ ). These changes may be attributable to the fermentation of residual lactose in the cheeses by the starter culture that would result in acid production and a decreased $\mathrm{pH}$. These results agree with the results of Buriti et al. (2005), who observed significant reductions in $\mathrm{pH}$ levels during storage of Minas fresh cheeses made with homofermentative mesophilic milk culture, similar to the milk culture used in this study.

The CGM displayed lower syneresis values $(P<$ $0.05)$ than CCM for all assessed storage periods, and lower than CCGM after d 14 of storage. These findings may be attributable to the fact that $\kappa-\mathrm{CN}$ in goat milk exhibits a higher negative charge than in cow milk (Tziboula-Clarke, 2003), which dulls the attractive forces between micelles, thereby reducing syneresis. The CCM, CCGM, and CGM displayed increased ( $P$ $<0.05$ ) syneresis during the storage period (Figure 1c), possibly as a consequence of reduced $\mathrm{pH}$ because increasing the concentration of hydrogen ions and acidifying the product reduces repulsive forces between casein micelles, thereby promoting aggregation and whey expulsion (Fox et al., 2000).

A decrease $(P<0.05)$ in moisture content and an increase in syneresis values in all evaluated cheeses during refrigerated storage for $21 \mathrm{~d}$ were observed. However, CCM exhibited a significant moisture loss only on the first day of storage, whereas CCGM and CGM already exhibited significant moisture losses by d 14 of storage. Some researchers have reported that the use of specific lactic acid bacteria strains as starter cultures for cheese production, as we did in this study, promotes coagulation by lowering the milk $\mathrm{pH}$, by aiding in the expulsion of whey from the curd (syneresis), and by reducing the cheese moisture content (Fox et al., 2000).

Table 2. Mean $( \pm \mathrm{SD})$ yield $(\mathrm{kg} / \mathrm{L})$ and chemical composition $(\mathrm{g} / 100 \mathrm{~g})$ values of Minas fresh cheeses made with cow milk, goat milk, or a mixture of the two

\begin{tabular}{lccc}
\hline & \multicolumn{3}{c}{ Cheese $^{1}$} \\
\cline { 2 - 4 } Variable & CCM & CCGM & CGM \\
\hline Yield $(\mathrm{kg} / \mathrm{L})$ & $19.40 \pm 1.08^{\mathrm{a}}$ & $18.99 \pm 0.45^{\mathrm{a}}$ & $17.61 \pm 0.92^{\mathrm{a}}$ \\
Moisture $(\mathrm{g} / 100 \mathrm{~g})$ & $63.97 \pm 1.84^{\mathrm{a}}$ & $64.14 \pm 2.25^{\mathrm{a}}$ & $63.97 \pm 2.35^{\mathrm{a}}$ \\
Protein $(\mathrm{g} / 100 \mathrm{~g})$ & $15.35 \pm 1.12^{\mathrm{a}}$ & $14.43 \pm 2.36^{\mathrm{a}}$ & $15.78 \pm 0.82^{\mathrm{a}}$ \\
Fat $(\mathrm{g} / 100 \mathrm{~g})$ & $17.44 \pm 1.42^{\mathrm{a}}$ & $17.78 \pm 1.48^{\mathrm{a}}$ & $16.44 \pm 0.73^{\mathrm{a}}$ \\
Lactose $(\mathrm{g} / 100 \mathrm{~g})$ & $1.60 \pm 0.14^{\mathrm{a}}$ & $1.36 \pm 0.16^{\mathrm{ab}}$ & $1.26 \pm 0.18^{\mathrm{b}}$ \\
Ash $(\mathrm{g} 100 / \mathrm{g})$ & $2.21 \pm 0.32^{\mathrm{a}}$ & $2.34 \pm 0.22^{\mathrm{a}}$ & $2.26 \pm 0.31^{\mathrm{a}}$ \\
\hline
\end{tabular}

${ }_{\mathrm{a}, \mathrm{b}}$ Within a row, different superscript letters indicate significant differences by the Tukey test $(P<0.05)$.

${ }^{1} \mathrm{CCM}=$ cheese made with cow milk; CCGM = cheese made with a mixture of cow milk and goat milk; CGM

$=$ cheese made with goat milk. 
a)

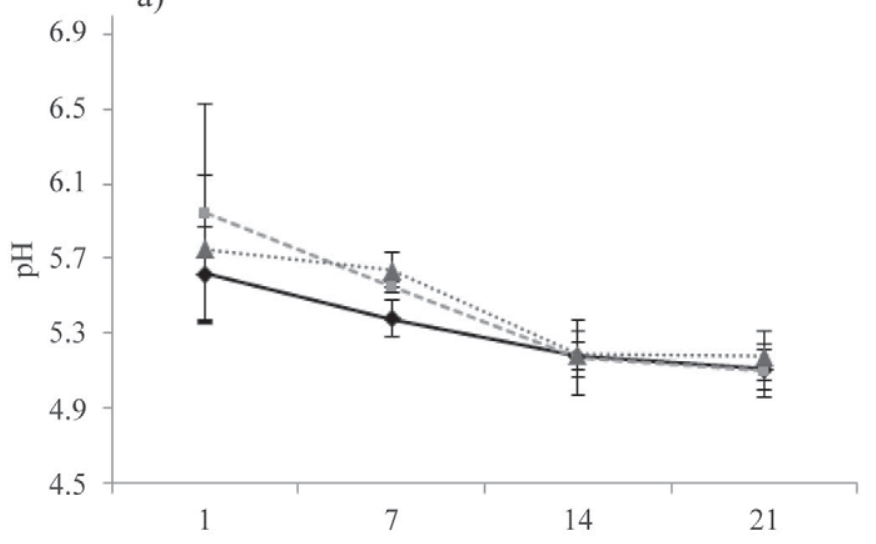

b)

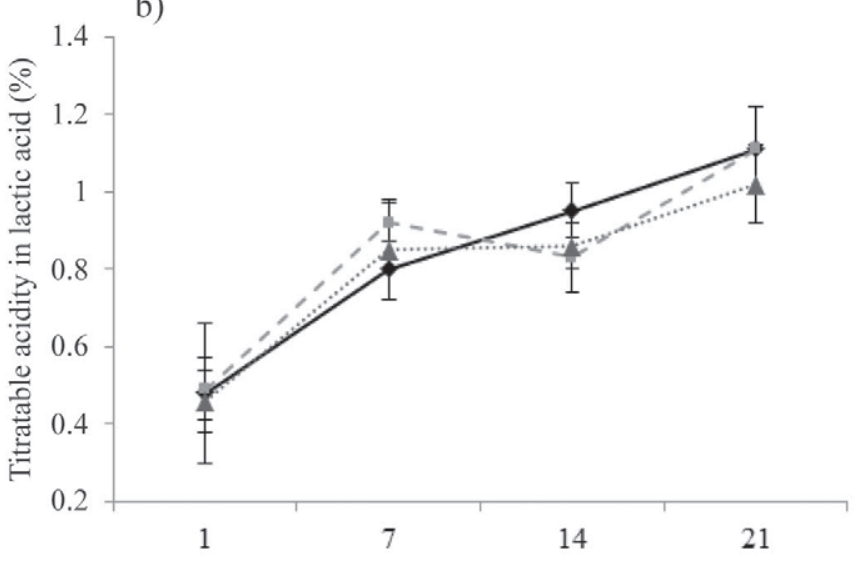

c)

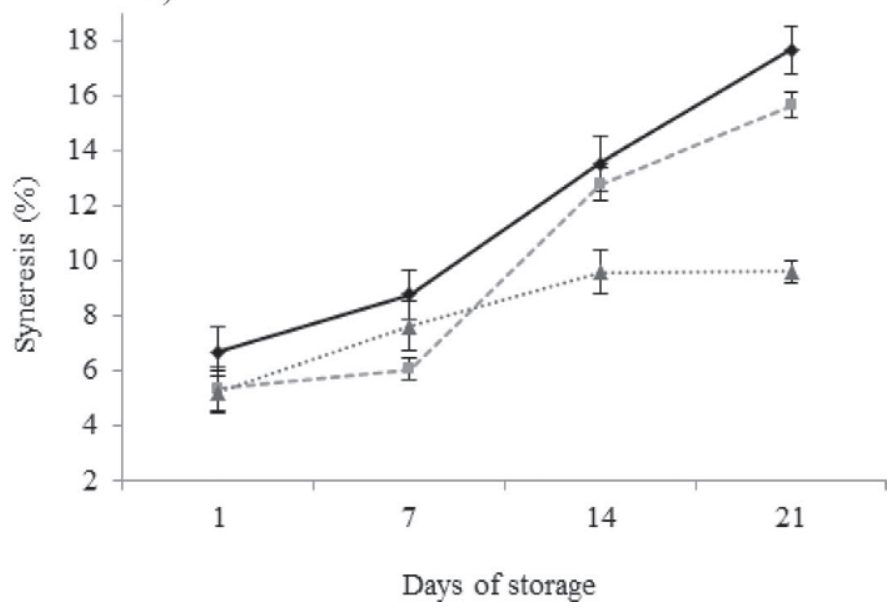

Figure 1. Mean values for $\mathrm{pH}(\mathrm{a})$, titratable acidity in lactic acid (b), and syneresis (c) of Minas fresh cheeses made with cow milk $(\mathrm{CCM} ;--)$, goat milk (CGM; $\cdots \mathbf{\Delta} \cdots)$, or a mixture of the two (CCGM; --- ) and stored for $21 \mathrm{~d}$ at $4^{\circ} \mathrm{C}$. Error bars indicate the standard deviation.

\section{Instrumental Color}

The CCM, CCGM, and CGM displayed high luminosity (high $\mathrm{L}^{*}$ ) values; however, CGM exhibited values higher $(P<0.05)$ than CCM and CCGM values (Table $3)$. Cheese prepared with goat milk demonstrated a more intense white color compared with cheese prepared with cow milk because goats convert all $\beta$-carotene present in the milk into vitamin A (Park et al., 2007). Álvarez et al. (2007) observed a positive correlation between the moisture content and luminosity in cheeses made with goat milk, suggesting that a high moisture content results in lighter products. Throughout the storage period, all the cheeses displayed decreased $(P$ $<0.05)$ luminosity with decreased $\mathrm{L}^{*}$ values. Similar results have been observed in Minas fresh cheese made with cow milk over 28 d of refrigerated storage (FritzenFreire et al., 2010).

The lowest $\mathrm{a}^{*}$ values $(P<0.05)$ were observed in CGM from d 14 of storage onward, indicating greener tones in CGM compared with CCM and CCGM. Queiroga et al. (2013) observed different behaviors in cheese made with goat milk, which displayed less intense green tones than cheese made with cow milk during $28 \mathrm{~d}$ of storage.

The $\mathrm{b}^{*}$ values (yellow component) were higher in CCM $(P<0.05)$ compared with CCGM and CGM. More intense yellowing in cheeses manufactured with cow milk than with goat milk was also observed by Sheehan et al. (2009). Cows transfer high carotenoid levels from their diet to milk and, consequently, dairy products made with cow milk are more yellow than those prepared with milk from other species (Fox and Cogan, 2004). During the 21 d of storage, only CGM displayed significantly increased $(P<0.05) \mathrm{b}^{*}$ values. Thus, the cheese samples demonstrated high luminosity $\left(\mathrm{L}^{*}\right)$, with a predominantly yellow component $\left(\mathrm{b}^{*}\right)$ rather than a green component $\left(-\mathrm{a}^{*}\right)$, suggesting that a white-yellowish tone contributed more to the final color of cheeses.

\section{Changes in the EPI and in the DPI}

The EPI values observed for CCM were lower $(P$ $<0.05$ ) than for CCGM and CGM only after $1 \mathrm{~d}$ of storage (final product). The EPI values observed for CCGM and CGM decreased $(P<0.05)$ during the refrigerated storage period, whereas CCM did not display any changes $(P>0.05)$ for this parameter (Figure $2 \mathrm{a}$ ). The EPI value correlates with natural milk proteinases and coagulant agents, which degrade protein into peptides of high molecular weight. However, when milk proteinases are inactivated by heat treatment (e.g., the temperature to which milk is submitted to dur- 
Table 3. Mean $( \pm \mathrm{SD})$ color parameter values of Minas fresh cheeses made with cow milk, goat milk, or a mixture of the two during $21 \mathrm{~d}$ of storage at $4^{\circ} \mathrm{C}$

\begin{tabular}{lcccc}
\hline & & \multicolumn{3}{c}{ Cheese $^{2}$} \\
\cline { 3 - 5 } Color $_{\text {parameter }^{1}}$ & $\begin{array}{c}\text { Days of } \\
\text { storage }\end{array}$ & CCM & CCGM & CGM \\
\hline L $^{*}$ & 1 & $93.54 \pm 0.80^{\mathrm{b}, \mathrm{A}}$ & $93.95 \pm 0.95^{\mathrm{b}, \mathrm{A}}$ & $95.36 \pm 0.75^{\mathrm{a}, \mathrm{A}}$ \\
& 7 & $92.86 \pm 0.35^{\mathrm{b}, \mathrm{AB}}$ & $92.97 \pm 0.50^{\mathrm{b}, \mathrm{AB}}$ & $94.29 \pm 0.51^{\mathrm{a}, \mathrm{B}}$ \\
& 14 & $92.30 \pm 0.68^{\mathrm{b}, \mathrm{B}}$ & $92.72 \pm 0.85^{\mathrm{ab}, \mathrm{B}}$ & $93.72 \pm 0.63^{\mathrm{a}, \mathrm{B}}$ \\
$\mathrm{a}^{*}$ & 21 & $92.28 \pm 0.45^{\mathrm{b}, \mathrm{B}}$ & $92.66 \pm 0.47^{\mathrm{b}, \mathrm{B}}$ & $93.35 \pm 0.43^{\mathrm{a}, \mathrm{B}}$ \\
& 1 & $-3.16 \pm 0.23^{\mathrm{a}, \mathrm{A}}$ & $-3.13 \pm 0.40^{\mathrm{a}, \mathrm{A}}$ & $-3.09 \pm 0.34^{\mathrm{a}, \mathrm{A}}$ \\
& 7 & $-3.16 \pm 0.28^{\mathrm{a}, \mathrm{A}}$ & $-3.32 \pm 0.23^{\mathrm{a}, \mathrm{A}}$ & $-3.30 \pm 0.17^{\mathrm{a}, \mathrm{A}}$ \\
& 14 & $-3.10 \pm 0.07^{\mathrm{a}, \mathrm{A}}$ & $-2.99 \pm 0.12^{\mathrm{a}, \mathrm{A}}$ & $-3.28 \pm 0.14^{\mathrm{b}, \mathrm{A}}$ \\
$\mathrm{b}^{*}$ & 21 & $-3.22 \pm 0.43^{\mathrm{a}, \mathrm{A}}$ & $-3.44 \pm 0.34^{\mathrm{a}, \mathrm{A}}$ & $-3.87 \pm 0.09^{\mathrm{b}, \mathrm{B}}$ \\
& 1 & $16.34 \pm 1.63^{\mathrm{a}, \mathrm{A}}$ & $13.70 \pm 0.83^{\mathrm{b}, \mathrm{A}}$ & $9.15 \pm 0.60^{\mathrm{c}, \mathrm{C}}$ \\
& 7 & $16.45 \pm 0.78^{\mathrm{a}, \mathrm{A}}$ & $13.97 \pm 0.72^{\mathrm{b}, \mathrm{A}}$ & $9.93 \pm 0.46^{\mathrm{c}, \mathrm{B}}$ \\
& 14 & $16.46 \pm 1.16^{\mathrm{a}, \mathrm{A}}$ & $14.14 \pm 0.31^{\mathrm{b}, \mathrm{A}}$ & $10.21 \pm 0.99^{\mathrm{c}, \mathrm{B}}$ \\
& 21 & $16.52 \pm 0.69^{\mathrm{a}, \mathrm{A}}$ & $14.29 \pm 0.32^{\mathrm{b}, \mathrm{A}}$ & $11.07 \pm 0.23^{\mathrm{c}, \mathrm{A}}$ \\
\hline
\end{tabular}

\footnotetext{
${ }^{\mathrm{a}-\mathrm{c}}$ Different lowercase superscript letters within a row denote differences $(P<0.05)$ between the values obtained for the different trials according to the Tukey test.

${ }^{\mathrm{A}-\mathrm{C}}$ For each color parameter, different capital superscript letters within a column denote differences $(P<0.05)$ between values obtained for different days of storage according to the Tukey test.

${ }^{1} \mathrm{~L}^{*}$ represents the lightness of the color $\left(\mathrm{L}^{*}=0\right.$ yields black and $\mathrm{L}^{*}=100$ indicates diffuse white), $\mathrm{a}^{*}$ represents its position between red/magenta and green (negative values indicate green, whereas positive values indicate magenta), and $b^{*}$ represents its position between yellow and blue (negative values indicate blue, whereas positive values indicate yellow).

${ }^{2} \mathrm{CCM}=$ cheese made with cow milk; CCGM = cheese made with a mixture of cow milk and goat milk; CGM $=$ cheese made with goat milk.
}

ing cheese manufacturing), they may not contribute to the primary proteolysis of cheeses (Pereira et al., 2008). The EPI results suggest that the residual enzymes of the coagulant agent exhibited greater effects in the early days of cheese storage but gradually were inactivated, or their substrates were depleted during increasing storage time.

The DPI, which represents the presence of small- and medium-chain peptides and free amino acids, was not different $(P>0.05)$ between the distinct cheese types evaluated (Figure 2b). However, DPI values increased in all cheeses, particularly in the last weeks of storage, suggesting that broken, high-molecular-weight peptides were released during the initial storage period (Delgado et al., 2011). The increased DPI values observed in the studied cheeses may be attributable to the action of lactic acid bacteria, which harbor complex proteolytic systems with enzymes that act primarily to degrade intermediate-sized peptides produced from casein as a result of chymosin or plasmin activity (McSweeney, 2004).

\section{Instrumental Texture Profile}

The CCGM displayed higher hardness $(P<0.05)$ than CCM and CGM only after $24 \mathrm{~h}$ of storage (final product). All evaluated cheeses displayed a decreased $(P<0.05)$ hardness over $21 \mathrm{~d}$ of refrigerated storage (Table 4). According to McSweeney (2004), cheese tex- ture softens during ripening as a result of casein micelle hydrolysis due to proteolysis, modifying the binding capacity of curd water and changes in $\mathrm{pH}$. Once all the cheeses displayed a decreased $\mathrm{pH}$ during storage, reaching values below 5.5 for CCM and CCGM from d 7 of storage and for CGM from d 14 of storage, colloidal calcium phosphate loss from the casein submicelles became apparent and promoted the progressive dissociation of these submicelles into smaller aggregates, which resulted in a more fragile cheese texture (Buriti et al., 2005).

Minas fresh cheese exhibits a high moisture content, which is recognized as an important factor in the evolution of cheese texture. Ahmed et al. (2005) reported that high-moisture-content cheeses harbor a fragile protein network that results in less-firm cheeses.

Generally, the type of milk used to manufacture cheese and the length of storage did not affect $(P>$ 0.05 ) the adhesiveness, elasticity, or cohesiveness of the cheeses studied. Buriti et al. (2007) also observed a lack of differences in these parameters in Minas fresh cheese made with cow milk stored for $21 \mathrm{~d}$ under refrigeration. Bryant et al. (1995) reported that cheese cohesiveness and elasticity are related to the structure of the protein network and the moisture and fat content.

Due to the decreased hardness, the derived parameters (gumminess and chewiness) were also influenced by the storage period. The CCM and CCGM displayed decreased $(P<0.05)$ gumminess and chewiness val- 


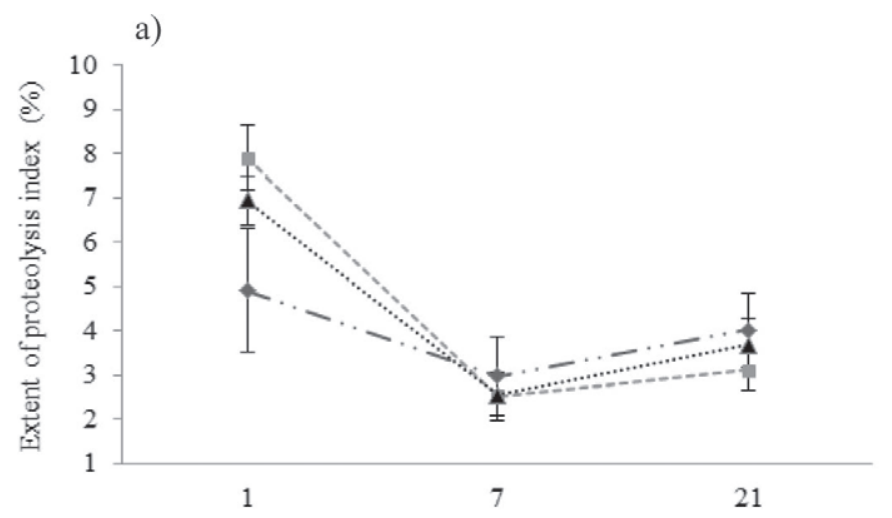

b)

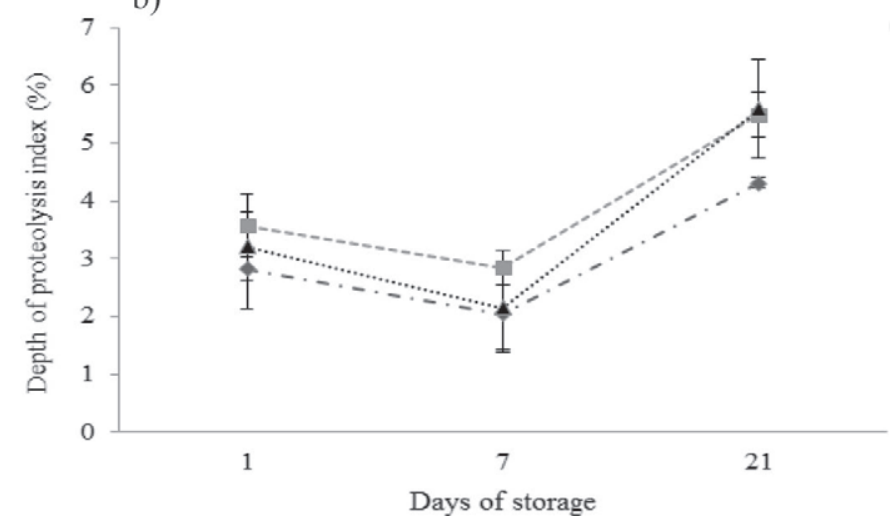

Figure 2. Mean extent of proteolysis index (a) and depth of proteolysis index (b) values for cheeses made with cow milk (CCM; $-\cdots-\cdots-$ ), goat milk (CGM; $\cdots \mathbf{\Delta} \cdots)$, or a mixture of the two (CCGM; --) during $21 \mathrm{~d}$ of storage at $4^{\circ} \mathrm{C}$. Error bars indicate the standard deviation.

ues over the storage period evaluated, whereas this behavior was not observed in CGM. Souza and Saad (2009) reported lower hardness, gumminess, and chewiness values in Minas fresh cheese made with cow milk compared with those found in the current study. The differences in the cheese texture parameters are attributable to the initial composition of milk and cheese, the manufacturing process, and the extent of the proteolysis index (Lucey et al., 2003).

\section{FA Profile}

Medium- and long-chain SFA (C14:0, C16:0, and C18:0) and PUFA (cis C18:1n-9) were prevalent in all cheese types studied (Table 5 ). The storage period did not change $(P>0.05)$ the FA profile, except for the amounts of caprylic (C8:0) and capric acid (C10:0). The C8:0 percentage was higher $(P<0.05)$ in CCGM on $\mathrm{d} 7$ of storage compared with CGM. However, on $\mathrm{d}$ 14 of storage, CCM and CGM displayed increased $(P$ $<0.05)$ FA content, which was not observed in CCGM. During both evaluated storage periods, CGM demon- strated a higher $(P<0.05)$ capric acid content $(\mathrm{C} 10: 0)$, whereas CCGM displayed an increase in this FA after d 13 of storage compared with CCM.

Differences were not observed in the medium-chain FA (C12:0, C14:0, and C16:0) and the long-chain FA (C18:0) levels $(P>0.05)$ in the cheeses throughout the storage period evaluated. Lucas et al., (2008) demonstrated higher C12:0 amounts in cheeses made with goat milk, whereas cheeses made with cow milk exhibited higher amounts of C14:0 and C16:0.

Greater amounts of oleic acid (cis C18:1n-9) and linoleic acid (cis C18:2n-6; $P<0.05$ ) were observed in CGM from both storage periods assessed. The CCGM displayed higher amounts of cis C18:2n-6 compared with $\mathrm{CCM}$ on the first day of storage, suggesting that the goat and cow milk mixture contributed to an increase in the amount of this FA. Goats respond differently to dietary factors than cows, both in fat secretion and in the FA composition of milk (Chilliard et al., 2003). These different responses are dependent on the metabolism and biohydrogenation of FA in the rumen obtained from feeding goat and cattle species, therefore resulting in the production of $\mathrm{C} 18: 0$ and some monoand polyunsaturated isomers (Chilliard et al., 2007), such as oleic acid and linoleic acid. A higher saturation of the biohydrogenation of dietary FA in the rumen of these animals results in a higher production of C18:0 and lower production of long-chain unsaturated FA (Lucas et al., 2008).

\section{Sensory Analysis}

In both storage periods evaluated, CCM received higher scores $(P<0.05)$ for creamy color and butter flavor and aroma, whereas CGM received higher scores $(P<0.05)$ for whitish color and goat milk aroma and flavor compared with CCM and CCGM (Figures 3a and $3 \mathrm{~b}$ ). The mixture of goat milk and cow milk promoted a decrease $(P<0.05)$ in creamy color and an increase in the white color of CCGM compared with CGM, and the differences in color reported by evaluators are consistent with instrumental color results, where CGM received the highest scores for white color, but a creamy color was more perceived in CCM.

The higher short-chain FA contents promote the typical aroma and flavor of the dairy products made with goat milk (Karademir et al., 2002), evidenced by the intermediate scores assigned to CCGM for aroma and flavor attributes of goat milk, which indicate the perception of aspects typical of goat milk.

The cheeses evaluated did not differ $(P>0.05)$ in their smooth appearance, soft and homogeneous texture, or salty and acidic flavor; moreover, the acidic flavor became more pronounced $(P<0.05)$ on $\mathrm{d} 14$ 
Table 4. Mean $( \pm \mathrm{SD})$ instrumental texture profile values of Minas fresh cheeses made with cow milk, goat milk, or a mixture of the two during $21 \mathrm{~d}$ of storage at $4^{\circ} \mathrm{C}$

\begin{tabular}{|c|c|c|c|c|}
\hline \multirow{2}{*}{$\begin{array}{l}\text { Texture } \\
\text { variable }\end{array}$} & \multirow{2}{*}{$\begin{array}{l}\text { Days of } \\
\text { storage }\end{array}$} & \multicolumn{3}{|c|}{ Cheese $^{1}$} \\
\hline & & $\mathrm{CCM}$ & CCGM & CGM \\
\hline \multirow[t]{4}{*}{ Hardness (N) } & 1 & $11.96 \pm 0.39^{\mathrm{b}, \mathrm{A}}$ & $14.19 \pm 0.02^{\mathrm{a}, \mathrm{A}}$ & $12.67 \pm 0.28^{\mathrm{b}, \mathrm{A}}$ \\
\hline & 7 & $12.12 \pm 0.97^{\mathrm{a}, \mathrm{A}}$ & $12.28 \pm 0.25^{\mathrm{a}, \mathrm{B}}$ & $9.20 \pm 1.00^{\mathrm{a}, \mathrm{AB}}$ \\
\hline & 14 & $7.69 \pm 0.51^{\mathrm{a}, \mathrm{B}}$ & $10.47 \pm 0.07^{\mathrm{a}, \mathrm{C}}$ & $7.64 \pm 1.72^{\mathrm{a}, \mathrm{B}}$ \\
\hline & 21 & $6.27 \pm 0.02^{\mathrm{a}, \mathrm{B}}$ & $8.01 \pm 0.06^{\mathrm{a}, \mathrm{D}}$ & $7.58 \pm 0.80^{\mathrm{a}, \mathrm{B}}$ \\
\hline \multirow{4}{*}{ Adhesiveness (N/s) } & 1 & $-0.19 \pm 1.40^{\mathrm{a}, \mathrm{A}}$ & $-0.21 \pm 0.35^{\mathrm{a}, \mathrm{A}}$ & $-0.20 \pm 0.30^{\mathrm{a}, \mathrm{A}}$ \\
\hline & 7 & $-0.26 \pm 1.15^{\mathrm{a}, \mathrm{A}}$ & $-0.24 \pm 0.65^{\mathrm{a}, \mathrm{A}}$ & $-0.24 \pm 0.54^{\mathrm{a}, \mathrm{A}}$ \\
\hline & 14 & $-0.27 \pm 0.25^{\mathrm{a}, \mathrm{A}}$ & $-0.25 \pm 0.44^{\mathrm{a}, \mathrm{A}}$ & $-0.25 \pm 0.32^{\mathrm{a}, \mathrm{A}}$ \\
\hline & 21 & $-0.25 \pm 0.03^{\mathrm{a}, \mathrm{A}}$ & $-0.26 \pm 0.39^{\mathrm{a}, \mathrm{A}}$ & $-0.25 \pm 2.22^{\mathrm{a}, \mathrm{A}}$ \\
\hline \multirow[t]{4}{*}{ Gumminess (N) } & 1 & $7.08 \pm 1.40^{\mathrm{a}, \mathrm{A}}$ & $4.64 \pm 0.35^{\mathrm{a}, \mathrm{A}}$ & $5.51 \pm 0.30^{\mathrm{a}, \mathrm{A}}$ \\
\hline & 7 & $3.83 \pm 1.15^{\mathrm{a}, \mathrm{AB}}$ & $3.97 \pm 0.65^{\mathrm{a}, \mathrm{AB}}$ & $5.29 \pm 0.54^{\mathrm{a}, \mathrm{A}}$ \\
\hline & 14 & $2.57 \pm 0.25^{\mathrm{a}, \mathrm{B}}$ & $3.02 \pm 0.44^{\mathrm{a}, \mathrm{AB}}$ & $3.90 \pm 0.32^{\mathrm{a}, \mathrm{A}}$ \\
\hline & 21 & $2.53 \pm 0.03^{\mathrm{a}, \mathrm{B}}$ & $2.49 \pm 0.39^{\mathrm{a}, \mathrm{B}}$ & $3.80 \pm 2.22^{\mathrm{a}, \mathrm{A}}$ \\
\hline \multirow[t]{4}{*}{ Chewiness $(\mathrm{N})$} & 1 & $5.86 \pm 0.96^{\mathrm{a}, \mathrm{A}}$ & $3.83 \pm 0.30^{\mathrm{a}, \mathrm{A}}$ & $4.63 \pm 0.34^{\mathrm{a}, \mathrm{A}}$ \\
\hline & 7 & $3.07 \pm 1.14^{\mathrm{a}, \mathrm{AB}}$ & $3.28 \pm 0.80^{\mathrm{a}, \mathrm{AB}}$ & $4.52 \pm 0.65^{\mathrm{a}, \mathrm{A}}$ \\
\hline & 14 & $2.06 \pm 0.24^{\mathrm{a}, \mathrm{B}}$ & $2.52 \pm 0.32^{\mathrm{ab}, \mathrm{AB}}$ & $3.30 \pm 0.19^{\mathrm{a}, \mathrm{A}}$ \\
\hline & 21 & $2.15 \pm 0.01^{\mathrm{a}, \mathrm{B}}$ & $2.11 \pm 0.31^{\mathrm{a}, \mathrm{B}}$ & $3.38 \pm 2.36^{\mathrm{a}, \mathrm{A}}$ \\
\hline \multirow[t]{4}{*}{ Cohesiveness } & 1 & $0.59 \pm 0.10^{\mathrm{a}, \mathrm{A}}$ & $0.33 \pm 0.02^{\mathrm{a}, \mathrm{A}}$ & $0.44 \pm 0.03^{\mathrm{a}, \mathrm{A}}$ \\
\hline & 7 & $0.32 \pm 0.12^{\mathrm{a}, \mathrm{A}}$ & $0.32 \pm 0.04^{\mathrm{a}, \mathrm{A}}$ & $0.58 \pm 0.00^{\mathrm{a}, \mathrm{A}}$ \\
\hline & 14 & $0.34 \pm 0.06^{\mathrm{a}, \mathrm{A}}$ & $0.29 \pm 0.04^{\mathrm{a}, \mathrm{A}}$ & $0.52 \pm 0.07^{\mathrm{a}, \mathrm{A}}$ \\
\hline & 21 & $0.40 \pm 0.01^{\mathrm{a}, \mathrm{A}}$ & $0.31 \pm 0.05^{\mathrm{a}, \mathrm{A}}$ & $0.49 \pm 0.24^{\mathrm{a}, \mathrm{A}}$ \\
\hline \multirow[t]{4}{*}{ Elasticity } & 1 & $0.83 \pm 0.03^{\mathrm{a}, \mathrm{A}}$ & $0.82 \pm 0.02^{\mathrm{a}, \mathrm{A}}$ & $0.84 \pm 0.02^{\mathrm{a}, \mathrm{A}}$ \\
\hline & 7 & $0.79 \pm 0.01^{\mathrm{a}, \mathrm{A}}$ & $0.83 \pm 0.04^{\mathrm{a}, \mathrm{A}}$ & $0.82 \pm 0.03^{\mathrm{a}, \mathrm{A}}$ \\
\hline & 14 & $0.80 \pm 0.06^{\mathrm{a}, \mathrm{A}}$ & $0.83 \pm 0.00^{\mathrm{a}, \mathrm{A}}$ & $0.85 \pm 0.12^{\mathrm{a}, \mathrm{A}}$ \\
\hline & 21 & $0.85 \pm 0.01^{\mathrm{a}, \mathrm{A}}$ & $0.85 \pm 0.01^{\mathrm{a}, \mathrm{A}}$ & $0.85 \pm 0.12^{\mathrm{a}, \mathrm{A}}$ \\
\hline
\end{tabular}

$\overline{\mathrm{a}, \mathrm{b}}$ Different lowercase superscript letters within a row denote differences $(P<0.05)$ between the values obtained for the different trials according to the Tukey test.

${ }^{\mathrm{A}-\mathrm{D}}$ For each texture variable, different capital superscript letters within a column denote differences $(P<0.05)$ between values obtained for different days of storage according to the Tukey test.

${ }^{1} \mathrm{CCM}=$ cheese made with cow milk; CCGM = cheese made with a mixture of cow milk and goat milk; CGM $=$ cheese made with goat milk.

Table 5. Mean $( \pm \mathrm{SD})$ FA majority content values $\left(\mathrm{g}^{-1}\right)$ in $100 \mathrm{~g}$ of Minas fresh cheeses produced with cow milk, goat milk, or a mixture of the two after 7 and $14 \mathrm{~d}$ of storage at $4^{\circ} \mathrm{C}$

\begin{tabular}{lcccc}
\hline & & & Cheese $^{1}$ & \\
\cline { 3 - 5 } FA & Days of & & & \\
\cline { 3 - 5 } & storage & CCGM & CGM \\
\hline C8:0 & 7 & $0.37 \pm 0.21^{\mathrm{ab}, \mathrm{B}}$ & $0.65 \pm 0.32^{\mathrm{a}, \mathrm{A}}$ & $0.01 \pm 0^{\mathrm{b}, \mathrm{B}}$ \\
& 14 & $0.98 \pm 0.15^{\mathrm{a}, \mathrm{A}}$ & $1.18 \pm 0.28^{\mathrm{a}, \mathrm{A}}$ & $1.24 \pm 0.13^{\mathrm{a}, \mathrm{A}}$ \\
$\mathrm{C} 10: 0$ & 7 & $2.07 \pm 0.10^{\mathrm{b}, \mathrm{B}}$ & $2.92 \pm 0.13^{\mathrm{b}, \mathrm{B}}$ & $4.02 \pm 0.68^{\mathrm{a}, \mathrm{B}}$ \\
& 14 & $2.62 \pm 0.10^{\mathrm{c}, \mathrm{A}}$ & $4.39 \pm 0.64^{\mathrm{b}, \mathrm{A}}$ & $5.67 \pm 0.03^{\mathrm{a}, \mathrm{A}}$ \\
$\mathrm{C} 12: 0$ & 7 & $2.83 \pm 0.10^{\mathrm{a}, \mathrm{A}}$ & $3.07 \pm 0.23^{\mathrm{a}, \mathrm{A}}$ & $3.00 \pm 0.57^{\mathrm{a}, \mathrm{A}}$ \\
& 14 & $2.93 \pm 0.12^{\mathrm{a}, \mathrm{A}}$ & $3.04 \pm 0.22^{\mathrm{a}, \mathrm{A}}$ & $3.23 \pm 0.58^{\mathrm{a}, \mathrm{A}}$ \\
C14:0 & 7 & $11.10 \pm 0.39^{\mathrm{a}, \mathrm{A}}$ & $10.69 \pm 0.64^{\mathrm{a}, \mathrm{A}}$ & $10.30 \pm 1.22^{\mathrm{a}, \mathrm{A}}$ \\
& 14 & $10.89 \pm 0.38^{\mathrm{a}, \mathrm{A}}$ & $10.42 \pm 0.61^{\mathrm{a}, \mathrm{A}}$ & $10.23 \pm 1.21^{\mathrm{a}, \mathrm{A}}$ \\
C16:0 & 7 & $32.05 \pm 1.21^{\mathrm{a}, \mathrm{A}}$ & $30.54 \pm 1.27^{\mathrm{a}, \mathrm{A}}$ & $29.56 \pm 2.19^{\mathrm{a}, \mathrm{A}}$ \\
& 14 & $31.20 \pm 1.71^{\mathrm{a}, \mathrm{A}}$ & $29.53 \pm 1.26^{\mathrm{a}, \mathrm{A}}$ & $28.79 \pm 2.16^{\mathrm{a}, \mathrm{A}}$ \\
C18:0 & 7 & $13.58 \pm 0.48^{\mathrm{a}, \mathrm{A}}$ & $12.72 \pm 1.12^{\mathrm{a}, \mathrm{A}}$ & $12.03 \pm 1.57^{\mathrm{a}, \mathrm{A}}$ \\
& 14 & $12.80 \pm 0.56^{\mathrm{a}, \mathrm{A}}$ & $12.36 \pm 0.98^{\mathrm{a}, \mathrm{A}}$ & $11.68 \pm 1.44^{\mathrm{a}, \mathrm{A}}$ \\
cis C18:1n-9 & 7 & $25.39 \pm 1.24^{\mathrm{b}, \mathrm{A}}$ & $26.75 \pm 1.17^{\mathrm{b}, \mathrm{A}}$ & $29.81 \pm 1.21^{\mathrm{a}, \mathrm{A}}$ \\
& 14 & $24.55 \pm 0.97^{\mathrm{b}, \mathrm{A}}$ & $26.30 \pm 1.16^{\mathrm{b}, \mathrm{A}}$ & $29.68 \pm 0.10^{\mathrm{a}, \mathrm{A}}$ \\
cis C18:2n-6 & 7 & $1.61 \pm 0.14^{\mathrm{b}, \mathrm{A}}$ & $1.91 \pm 0.08^{\mathrm{b}, \mathrm{A}}$ & $2.28 \pm 0.15^{\mathrm{a}, \mathrm{A}}$ \\
& 14 & $1.64 \pm 0.13^{\mathrm{b}, \mathrm{A}}$ & $1.96 \pm 0.02^{\mathrm{a}, \mathrm{A}}$ & $2.21 \pm 0.15^{\mathrm{a}, \mathrm{A}}$ \\
\hline
\end{tabular}

${ }^{a-c}$ Different lowercase superscript letters within a row denote differences $(P<0.05)$ between the values obtained for the different trials according to the Tukey test.

${ }^{\mathrm{A}, \mathrm{B}}$ For each FA, different capital superscript letters within a column denote differences $(P<0.05)$ between values obtained for different days of storage according to the Tukey test.

${ }^{1} \mathrm{CCM}=$ cheese made with cow milk; CCGM $=$ cheese made with a mixture of cow milk and goat milk; CGM $=$ cheese made with goat milk. 
(a)

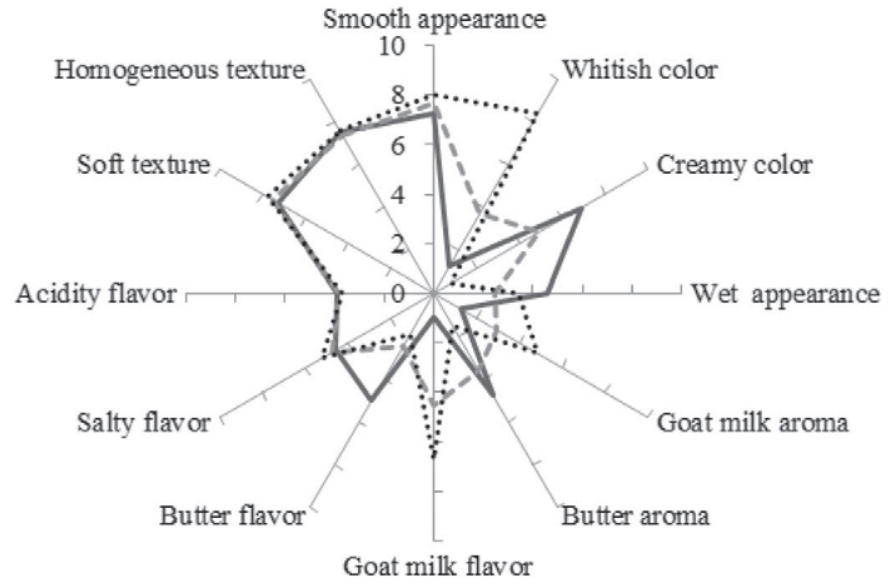

(b)

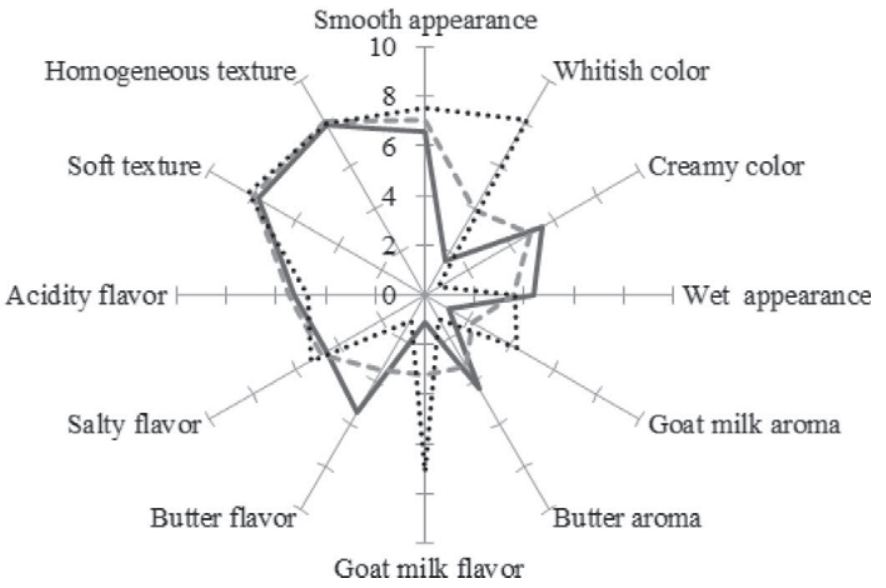

Figure 3. Graphic representation of the sensory evaluation by quantitative descriptive analysis of Minas fresh cheeses made with cow milk $(\mathrm{CCM} ;-)$, goat milk (CGM; $\cdots)$, or a mixture of the two (CCGM; ---) during storage at $4^{\circ} \mathrm{C}$. (a) $7 \mathrm{~d}$ of storage; (b) $14 \mathrm{~d}$ of storage.

of storage in all cheeses. Minas fresh cheese is typified by a slightly acidic flavor (da Cunha et al., 2006), which may be attributable to the titratable acidity profile exhibited by the cheeses evaluated and detected during their sensory analysis. The perceived softness reinforces the findings for the instrumental texture profile, which reflected low hardness values exhibited by all cheeses independent of the milk source. The CCM was described to exhibit a better wet appearance $(P<$ 0.05) compared with CGM and CCGM for both storage periods assessed, which corroborates the high syneresis displayed by CCM.

In the principal components analysis for sensory data, the first 2 principal components explained $100 \%$ of the total variance between samples. Thus, for graphing, 2 dimensions were presented (Figure 4). Principal component 1 explained $89.3 \%$ of the variability between cheeses and most strongly accounted for the differences between the samples. According to principal component 1 , the whitish color, smooth appearance, homogeneous texture, and goat milk flavor and aroma directly interacted with each other, and these attributes are inversely related to creamy color, salty and butter flavors, soft texture, and butter aroma. The dispersion of CCM, CCGM, and CGM samples in the graph agreed with results previously obtained for the sensory profile of cheese. Wadhwani and McMahon (2012) reported that the color of the cheese can change the flavor perception by consumers. The evaluators may have associated the creamy color with the flavor of butter, including the salty flavor.

According to Salvador et al. (2009), the correlation of 2 or more parameters with 1 main component indicates that these parameters are related. The same correlation for parameters with the same main com- ponent represents a direct relationship between these variables, and a correlation in the opposite direction indicates an inverse relationship (Silva et al., 2010). Sensory descriptors, such as "wet appearance" and "acidic flavor," were explained by principal component 2 , and the vectors that represent them indicate a direct relationship between these attributes because the acid production (and consequent $\mathrm{pH}$ reduction) promotes the release of whey from cheese (syneresis) (Fox et al.,

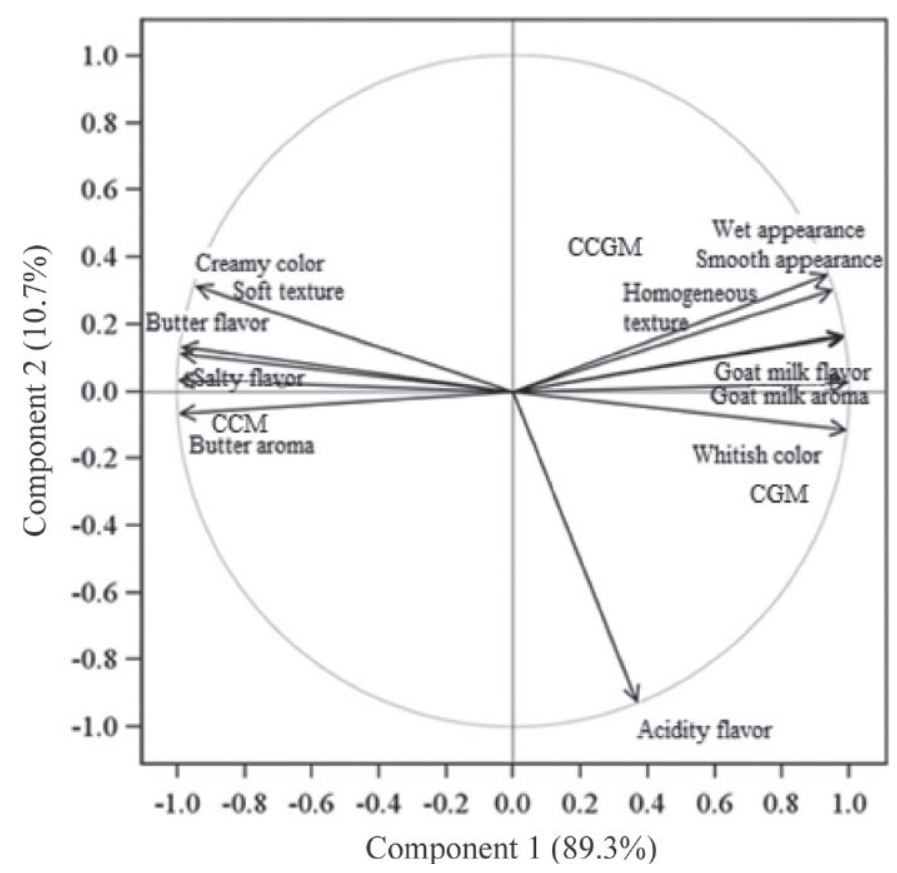

Figure 4. Principal components analysis of the sensory attributes of Minas fresh cheeses made with cow milk (CCM), goat milk (CGM), or a mixture of the two (CCGM). 
2000). This principal component explains $10.7 \%$ of the variability between samples, playing a minor role in differentiating the studied cheeses, which is in agreement with Figures 3a and 3b, where the samples exhibited similar attributes.

The purchase intent of cheese samples revealed differences $(P<0.05)$ between the cheeses, where CCM reached the highest scores and CGM reached the lowest mean values (data not shown). However, all scores remained between 4 and 5, which indicates that the evaluators would certainly buy the product, revealing the likely approval of all Minas fresh cheeses.

\section{CONCLUSIONS}

Minas fresh cheese produced with cow milk, goat milk, and a mixture of the two demonstrated similar physicochemical properties during $21 \mathrm{~d}$ of storage. Timedependent changes were observed only for proteolysis, syneresis, moisture, acidity, and instrumental hardness, whereas the FA profiles were not considerably different. However, the use of goat milk yielded higher percentages of caprylic, capric, oleic, and linoleic FA compared with cheese made with cow milk. Likewise, Minas fresh cheeses manufactured with cow milk, goat milk, and a mixture of the two displayed some similar sensory attributes; however, they differed in flavor, aroma, and color because the use of goat milk promoted an increase in whitish color and intensified the unique flavor and aroma typical of this milk. The development of derivative products, particularly Minas fresh cheese, where goat milk is partially substituted with cow milk, can be a viable alternative for marketable, high-quality dairy products that meet consumer demands.

\section{ACKNOWLEDGMENTS}

The authors thank the National Council for Scientific and Technological Development (CNPq, Brasília, Brazil) for financial support and the Center for Humanities, Social and Agrarian Sciences, Federal University of Paraíba (CCHSA/UFPB, João Pessoa, Brazil) for supplying the milk used to prepared the cheeses studied.

\section{REFERENCES}

Agência Nacional de Vigilância Sanitária. 2001. Resolução RDC nº 12, de 02 de janeiro de 2001. Regulamento Técnico sobre os padrões microbiológicos para alimentos. Diário Oficial da União, Brasília, Brazil.

Ahmed, N. H., M. El Soda, A. N. Hassan, and J. Frank. 2005. Improving the textural properties of an acid-coagulated (Karish) cheese using exopolysaccharide producing cultures. Lebenson. Wiss. Technol. 38:843-847.

Álvarez, S., V. Rodríguez, M. E. Ruiz, and M. Fresno. 2007. Correlaciones de textura y color instrumental con la composición química de quesos de cabra Canários. Arch. Zootech. 56(Suppl 1):663-666.

Andreatta, E., A. M. Fernandes, M. V. dos Santos, C. G. de Lima, C. Mussarelli, M. C. Marques, and C. A. F. de Oliveira. 2007. Effects of milk somatic cell count on physical and chemical characteristics of Mozzarella cheese. Aust. J. Dairy Technol. 62:166-170.

Andreatta, E., A. M. Fernandes, M. V. dos Santos, C. Mussarelli, M. C. Marques, M. L. Gigante, and C. A. F. de Oliveira. 2009. Quality of Minas frescal cheese prepared from milk with different somatic cell counts. Pesquisa Agropecuária Brasileira 44:320-326.

AOAC International. 2005. Official Methods of Analysis. 18th ed. AOAC International, Gaithersburg, MD.

APHA (American Public Health Association). 2001. Compendium of Methods for the Microbiological Examination of Foods. 4th ed. APHA, Washington, DC.

Bryant, A., Z. Ustunol, and J. Steffe. 1995. Texture of Cheddar cheese as influenced by fat reduction. J. Food Sci. 60:1216-1219.

Buriti, F. C. A., T. Y. Okazaki, J. H. A. Alegro, and S. M. I. Saad. 2007. Effect of a probiotic mixed culture on texture profile and sensory performance of Minas fresh cheese in comparison with the traditional products. Arch. Latinoam. Nutr. 57:179-185.

Buriti, F. C. A., J. S. da Rocha, E. G. Assis, and S. M. I. Saad. 2005 Probiotic potential of Minas fresh cheese prepared with the addition of Lactobacillus paracasei. Lebenson. Wiss. Technol. 38:173180.

Chilliard, Y., A. Ferlay, J. Rouel, and G. Lamberet. 2003. A review of nutritional and physiological factors affecting goat milk lipid synthesis and lipolysis. J. Dairy Sci. 86:1751-1770.

Chilliard, Y., F. Glasser, A. Ferlay, L. Bernard, J. Rouel, and M. Doreau. 2007. Diet, rumen biohydrogenation and nutritional quality of cow and goat milk fat. Eur. J. Lipid Sci. Technol. 109:828855.

CIE (Commission Internationale de l'Éclaraige). 1996. Colorimetry. 18th ed. CIE Publ., Vienna, Austria.

da Cunha, C. R., W. H. Viotto, and L. A. Viotto. 2006. Use of low concentration factor ultrafiltration retentates in reduced fat "Minas frescal" cheese manufacture: Effect on composition, proteolysis, viscoelastic properties and sensory acceptance. Int. Dairy J. $16: 215-224$

Delgado, F. J., J. González-Crespo, R. Cava, and R. Ramírez. 2011. Proteolysis, texture and colour of a raw goat milk cheese throughout the maturation. Eur. Food Res. Technol. 233:483-488.

dos Santos, K. M. O., M. A. D. Bomfim, A. D. S. Vieira, S. D. Benevides, S. M. I. Saad, F. C. A. Buriti, and A. S. Egito. 2012. Probiotic caprine Coalho cheese naturally enriched in conjugated linoleic acid as a vehicle for Lactobacillus acidophilus and beneficial fatty acids. Int. Dairy J. 24:107-112.

Dubeuf, J.-P. 2005. Structural, market and organisational conditions for developing goat dairy production systems. Small Rumin. Res. 60:67-74.

Folch, J., M. Lees, and G. H. Sloane Stanley. 1957. Simple method for the isolation and purification of total lipides from animal tissues. J. Biol. Chem. 226:497-509.

Fox, P. F., and T. M. Cogan. 2004. Factors that affect the quality of cheese. Pages 583-608 in Cheese: Chemistry, Physics and Microbiology. Vol. 1. General Aspects. P. F. Fox, L. H. P. McSweeney, T. M. Cogan and P. T. Guinee, ed. Elsevier Academic Press, San Diego, CA.

Fox, P. F., T. P. Guinee, T. M. Cogan, and P. L. H. McSweeney. 2000. Fundamentals of Cheese Science. Aspen Publishers Inc., Gaithersburg, MD.

Fritzen-Freire, C. B., C. M. O. Müller, J. B. Laurindo, R. D. de M. C. Amboni, and E. S. Prudêncio. 2010. The effect of direct acidification on the microbiological, physicochemical and sensory properties of probiotic Minas frescal cheese. Int. J. Dairy Technol. 63:561-568.

Guo, M., Y. W. Park, P. H. Dixon, J. A. Gilmore, and P. S. Kindstedt. 2004. Relationship between the yield of cheese (Chevre) and chemical composition of goat milk. Small Rumin. Res. 52:103-107.

Guo, M. R. 2003. Goat milk In Encyclopedia of Food Sciences and Nutrition. B. Caballero, ed. Academic Press, London, UK. 
Haenlein, G. F. W. 2004. Goat milk in human nutrition. Small Rumin. Res. 51:155-163.

Hartman, L., and R. C. A. Lago. 1973. Rapid preparation of fatty acid methyl esters from lipids. Lab. Pract. 22:475-476.

Karademir, E., M. Atamer, B. Tamucay, and S. Yaman. 2002. Some properties of goat milk yoghurts produced by different fortification methods. Milchwissenschaft 57:261-263.

Lucas, A., E. Rock, C. Agabriel, Y. Chilliard, and J. B. Coulon. 2008. Relationships between animal species (cow versus goat) and some nutritional constituents in raw milk farmhouse cheeses. Small Rumin. Res. 74:243-248.

Lucey, J. A., M. E. Johnson, and D. S. Horne. 2003. Perspectives on the basis of the rheology and texture properties of cheese. J. Dairy Sci. 86:2725-2743.

McSweeney, P. L. H. 2004. Biochemistry of cheese ripening. Int. J. Dairy Technol. 57:127-144.

Moatsou, A., M. Samolada, P. Panagiotou, and E. Anifantakis. 2004. Casein fraction of bulk milks from different caprine breeds. Food Chem. 87:75-81.

Park, Y. W. M. Juárez, M. Ramos, and G. F. W. Haenlein. 2007. Physico-chemical characteristics of goat and sheep milk. Small Rumin. Res. 68:88-113.

Pereira, C. I., E. O. Gomes, A. M. P. Gomes, and F. X. Malcata. 2008. Proteolysis in model Portuguese cheeses: Effects of rennet and starter culture. Food Chem. 108:862-868.

Queiroga, R. C. R. E., B. M. Santos, A. M. P. Gomes, M. J. Monteiro, S. M. Teixeira, E. L. de Souza, C. J. D. Pereira, and M. M. E. Estevez Pintado. 2013. Nutritional, textural and sensory properties of Coalho cheese made of goats', cows' milk and their mixture. Lebenson. Wiss. Technol. 50:538-544.

Salvador, A., P. Varela, T. Sanz, and S. M. Fiszman. 2009. Understanding potato chips crispy texture by simultaneous fracture and acoustic measurements, and sensory analysis. Lebenson. Wiss. Technol. 42:763-767.

SAS Institute. 2002. SAS User's Guide. SAS Institute Inc., Cary, NC. Sheehan, J. J., A. D. Patel, M. A. Drake, and P. L. H. McSweeney 2009. Effect of partial or total substitution of bovine for caprine milk on the compositional, volatile, non-volatile and sensory characteristics of semi-hard cheeses. Int. Dairy J. 19:498-509.

Silva, R. C. S. N., V. P. Rodrigues Minim, A. A. Simiqueli, L. E. da Silva Moraes, A. I. Gomide, and L. A. Minim. 2010. Optimized descriptive profile: A rapid methodology for sensory description. Food Qual. Prefer. 24:190-200.

Slačanac, V., R. Božanić, J. Hardi, J. R. Szabó, M. Lučan, and V. Krstanović. 2010. Nutritional and therapeutic value of fermented caprine milk. Int. J. Dairy Technol. 63:171-189.

Souza, C. H. B., and S. M. I. Saad. 2009. Viability of Lactobacillus acidophilus La-5 added solely or in co-culture with a yoghurt starter culture and implications on physico-chemical and related properties of Minas fresh cheese during storage. Lebenson. Wiss. Technol. 42:633-640.

Stone, L. H. J., and L. Sidel. 1993. Sensory Evaluation Practices. 2nd ed. Academic Press, London, UK.

Tziboula-Clarke, A. 2003. Goat milk. Pages 1270-1279 in Encyclopedia of Dairy Sciences. Vol. 2. H. Roginski, J. W. Fuquay, and P. F. Fox, ed. Academic Press, London, UK.

Vargas, M., M. Cháfer, A. Albors, A. Chiralt, and C. González-Martínez. 2008. Physicochemical and sensory characteristics of yoghurt produced from mixtures of cow's and goat's milk. Int. Dairy J. 18:1142-1152.

Wadhwani, R., and D. J. McMahon. 2012. Color of low-fat cheese influences flavor perception and consumer liking. J. Dairy Sci. 95:2336-2346. 